\title{
PERAN PENYULUH PERTANIAN TERHADAP HASIL PANEN PETANI PADI DI SIDOMUKTI SALATIGA
}

\author{
THE ROLE OF AGRICULTURAL EXTENSION ON RICE FARMERS YIELD \\ IN SIDOMUKTI SALATIGA
}

\author{
GREGORIUS BAGAS*, LASMONO TRI SUNARYANTO \\ Fakultas Pertanian dan Bisnis Universitas Kristen Satya Wacana Salatiga \\ *E-mail: pangestubagas564@ gmail.com
}

\begin{abstract}
ABSTRAK
Tujuan dari penelitian ini 1) Mengetahui upaya penyuluh dalam meningkatkan hasil panen petani padi di Sidomukti Salatiga. 2) Mengetahui perubahan hasil panen petani padi setelah diberikan penyuluhan. Penelitian ini menggunakan metode deskriptif kualitatif. Berdasarkan cara pengumpulan data, peneliti menggunakan metode observasi, wawancara dan dokumentasi. Analisis data yang digunakan yaitu dengan reduksi data, penyajian data, lalu penarikan kesimpulan. Uji keabsahan data yang digunakan yaitu dengan triangulasi. Petani padi di Sidomukti Salatiga sudah merasakan berbagai upaya yang dilakukan oleh penyuluh untuk meningkatkan hasil panen tanaman padi mereka. Pertemuan rutin dengan petani, gerakan pengendalian hama, anjangsana, demplot dan sekolah lapang merupakan beberapa upaya yang dilakukan penyuluh. Dari berbagai upaya yang dilakukan oleh penyuluh tersebut, petani pada akhirnya dapat merasakan hasil panen yang meningkat. Tidak semata-mata hasil panen petani yang selalu meningkat, tetapi petani padi di Sidomukti, Salatiga juga merasakan berbagai ilmu baru yang didapat dan kemudahan dalam usahatani mereka.
\end{abstract}

Kata Kunci : Upaya Penyuluh, Hasil Panen, Usahatani

\section{ABSTRACT}

The purpose of this study 1) To determine the efforts of extension workers in increasing the yield of rice farmers in Sidomukti Salatiga. 2) Knowing the changes in rice farmers' yields after being given counseling. This study used descriptive qualitative method. Based on the method of data collection, the researcher used the method of observation, interviews and documentation. The data analysis used is data reduction, data presentation, then drawing conclusions. Test the validity of the data used by triangulation. Rice farmers in Sidomukti Salatiga have experienced the various efforts made by extension workers to increase the yield of their rice crops. Regular meetings with farmers, pest control movements, anjangsana, demonstration plots and field schools are some of the efforts made by extension workers. From the various efforts made by the extension workers, farmers can finally feel the increased yields. It's not only farmers' yields that are always increasing, but rice farmers in Sidomukti, Salatiga also feel the new knowledge gained and the ease in their farming.

Keywords: Extension Efforts, Harvest Yield, Farming

\section{PENDAHULUAN}

Sektor pertanian di Indonesia memiliki kontribusi nyata dalam penyedia pangan, penyediaan bahan baku industri, menjaga pelestarian lingkungan, menyumbang produk domestik bruto, dan pendorong bergeraknya sektor ekonomi kreatif lainnya. Indonesia termasuk salah satu negara yang tercatat sebagai tingkatan tertinggi di dunia yang mengkonsumsi nasi/beras. Menurut Badan Pusat Statistik pada tahun 2015, didapatkan informasi bahwa produksi padi tahun 2014 di Indonesia sebesar 70,85 juta ton Gabah 
Kering Giling (GKG) yang mengalami penurunan sebesar 0,43 juta ton $(0,61$ persen) dibandingkan tahun 2013. Upaya meningkatkan dan mengembangan pertanian nasional terus dilakukan oleh pemerintah pusat. Penyuluhan Pertanian, Perikanan, dan Kehutanan (SP3K) yang merupakan salah satu cara yang dilakukan pemerintah untuk meningkatkan dan mengembangkan pertanian nasional. Diperlukan adanya motivator bagi petani agar mengubah cara berfikir maupun metode bertani yang lebih maju yang biasa disebut sebagai seorang penyuluh pertanian. (Yanto, 2016).

Menurut Amanah (2007), subyek dari ilmu penyuluhan adalah manusia yang sebagai bagian dari sebuah sistem sosial, sedangkan obyek dari materi ilmu penyuluhan adalah perilaku yang dihasilkan dari proses pendidikan atau pembelajaran, proses komunikasi dan sosial. Ilmu penyuluhan mampu menjelaskan bahwa transformasi perilaku manusia yang dirancang dengan menerapkan pendekatan pendidikan, komunikasi, dan sesuai dengan struktur sosial, ekonomi, budaya masyarakat, dan lingkungan fisiknya. Parameter dalam mengukur sebuah hasil kerja dari penyuluhan yang dapat dikatakan berhasil atau tidaknya adalah evaluasi dari proses kegiatan penyuluhan yang sudah dilakukan dan hasil laporan. Sebuah evaluasi dan laporan dapat dibagi dalam dua aspek, yaitu evaluasi yang menjadi dampak penyuluhan pertanian terhadap petani sebagai sasaran dan laporan dari hasil penyuluhan yang sudah dijalankan. Dari hasil laporan dan evaluasi yang sudah diberikan, maka kedua hal tersebut dapat dijadikan pembelajaran bagi penyuluh untuk memenuhi target dan memperbaiki hal yang belum bisa dijalankan (Sapar, 2012).

Hal tersebut menjadi latar belakang dilakukannya penelitian ini dengan tujuan (1) Mengetahui upaya penyuluh dalam meningkatkan hasil panen petani padi di Sidomukti, Salatiga (2) Mengetahui perubahan hasil petani padi setelah diberikan penyuluhan.

\section{METODE PENELITIAN}

\section{Jenis Penelitian}

Penelitian ini merupakan jenis penelitian deskriptif kualitatif. Deskriptif merupakan metode yang digunakan untuk mendeskripsikan atau memberi gambaran terhadap objek yang diteliti melalui data atau sampel yang telah terkumpul sebagaimana adanya tanpa membuat kesimpulan yang berlaku umum (Sugiyono, 2011). Metode penelitian kualitatif merupakan metode penelitian yang 
digunakan untuk mendeskripsikan dan menganalisis fenomena, peristiwa, aktivitas sosial, sikap, kepercayaan, persepsi, dan orang secara individual maupun kelompok.

\section{Tehnik Pengambilan Sampel}

Tujuan pengambilan sampel adalah untuk memperoleh gambaran deskriptif tentang karakteristik unit observasi yang termasuk di dalam data, dan untuk melakukan generalisasi serta memperkirakan parameter populasi. Teknik snowball adalah suatu metode untuk mengidentifikasi, memilih dan mengambil sampel dalam suatu jaringan atau rantai hubungan yang menerus (Neuman, 2003). Dari penelitian ini, terdapat 5 partisipan dan mengambil teknik snowball yang berawal dari 2 penyuluh kemudian mencari tahu partisipan berikutnya, yaitu 3 petani.

\section{Teknik Pengumpulan Data}

Teknik pengumpulan data dalam penelitian ini adalah wawancara, observasi, dan studi pustaka :

\section{1) Observasi}

Observasi menurut Herdiyansah (2010) merupakan proses mengamati dan mencermati suatu perilaku yang bertujuan untuk memperoleh informasi mengenai objek yang dijadikan variabel.

2) Wawancara

Menurut Moleong (2000), wawancara adalah percakapan yang dilakukan oleh dua belah pihak dengan tujuan tertentu, sehingga menghasilkan jawaban yang dicatat maupun direkam oleh pewawancara.

3) Studi Dokumentasi

Menurut Herdiyansah (2010), studi dokumentasi merupakan metode pengumpulan data kualitatif dengan menganalisis dokumen yang berasal dari subjek bahkan orang lain mengenai subjek tersebut. Studi dokumentasi bertujuan untuk menggambarkan sudut pandang subjek melalui media dan dokumen non lisan lainnya yang dibuat langsung oleh subjek yang bersangkutan.

\section{Uji Keabsahan}

Uji keabsahan hasil penelitian menggunakan metode triangulasi. Triangulasi yang digunakan pada penelitian ini adalah triangulasi sumber. Triangulasi sumber adalah pengecekan data yang diperoleh dari beberapa sumber untuk dideskripsikan kemudian dikategorikan berdasarkan sudut pandang informan. Data yang telah dianalisis kemudian dimintakan kesepakatan (member check) dengan sumber data tersebut. (Sugiyono, 2011).

\section{HASIL DAN PEMBAHASAN}

\section{Gambaran Umum Lokasi Penelitian}

Kota Salatiga memiliki wilayah administratif dengan luas 5.678 hektar, dengan ketinggian 450 - 825 mdpl. 
Keseluruhan wilayah berbatasan dengan wilayah administratif Kabupaten Semarang. Dengan luas administratif yang ada 799 hektar $(14,07 \%)$ merupakan lahan sawah, 4.680 hektar $(82,43 \%)$ merupakan lahan kering dan 199 hektar (3,5\%) adalah lahan lainnya. Terdapat empat Kecamatan di Salatiga yang mendapat penyuluhan dari Dinas Pertanian Kota Salatiga. Empat Kecamatan yang dimaksud adalah Argomulyo, Tingkir, Sidomukti, dan Sidorejo. Penulis memilih Kecamatan Sidomukti sebagai objek penelitian. Dari empat Kecamatan yang ada, Kecamatan Sidomukti memiliki 64,50 hektar lahan sawah. Setiap penyuluh Dinas Pertanian Salatiga di tempatkan dan bertanggung jawab atas Kecamatan dimana mereka ditempatkan. Penyuluh secara rutin mendampingi dan memberikan pelatihan kepada kelompok tani dengan datang pada pertemuan mingguan maupun bulanan kelompok tani.

\section{Tujuan Penyuluhan}

Penyuluh bisa dikatakan sebagai mitra petani, yang dimana salah satu fungsinya adalah penghubung antara pemerintah dan petani. Pelatihan-pelatihan yang diberikan penyuluh membutuhkan waktu atau proses yang cukup lama agar dapat diterima oleh petani. Penyuluh harus bisa membuat petani mengerti dan memahami apa tujuan akhir dari praktik penyuluhan. Bukan sekedar memberikan pelatihan kepada petani, penyuluh juga harus bisa membuat petani lebih memahami titik akhir dari sebuah penyuluhan selain kesejahteraan, yaitu pertanian yang berkelanjutan. Semakin berkembangnya zaman, petani juga harus diajarkan sifat yang lebih adaptif dalam usaha taninya untuk meningkatkan produktifitas. Penyuluh memberikan pelatihan-pelatihan kepada petani yang sekiranya petani belum pahami hingga membuat petani bisa, terutama mau dalam menerapkan sistem bertani yang baru. Berikut pernyataan yang disampaikan oleh penyuluh mengenai tujuan penyuluhan:

"Penyuluh adalah ee mitra petani sebagai hmm apa ya, menjembatani antara petani dengan pemerintah. Tapi kita lebih cenderung menyebutnya kita adalah mitra petani.Tujuan dari penyuluhan kan untuk merubah perilaku, sikap dan keterampilan petani. Dengan harapan, perilakunya berubah dalam melakukan usaha taninya, sikapnya berubah dan kemampuan dalam mengusaha tani berubah. Nanti ini ee nilai akhirnya adalah meningkatkan kesejahteraan petani. Iya, tujuan akhirnya itu. Meningkatkan hasil produksi, nanti dampaknya adalah kesejahteraan, he eh"

Upaya Meningkatkan Hasil Panen

Hasil panen yang maksimal merupakan keinginan semua petani. Petani akan melakukan berbagai cara untuk mendapatkan hasil panen yang maksimal. Begitu juga dengan penyuluh. Berbagai 
cara dilakukan oleh penyuluh di Sidomukti, Salatiga untuk ikut andil dalam memaksimalkan hasil panen petani padi.

Banyak program yang dimiliki oleh penyuluh, antara lain: gerakan pengendalian, anjangsana, tatap muka, demplot dan sekolah lapang/SLPHT. Gerakan pengendalian biasa di sebut GERDAL, merupakan pelatihan yang diberikan penyuluh kepada petani khusunya petani padi untuk mengendalikan hama. Kegiatan ini biasa dilakukan untuk memberi tahu petani racun apa yang tepat untuk digunakan, obat apa yang perlu digunakan, seberapa banyak dosis yang harus digunakan dengan sebuah demonstrasi cara. Kegiatan GERDAL dilakukan jika sebuah lahan pertanian mulai terkena hama yang cukup banyak, lalu penyuluh akan datang atau mendapat panggilan dari petani. Anjangsana adalah kunjungan-kunjungan yang dilakukan oleh penyuluh ke petani yang memiliki tujuan agar mendekatkan penyuluh dengan petani. Demplot biasa disebut demonstrasi plot adalah contoh praktik secara langsung. Seperti penyuluh memberikan contoh praktik bagaimana cara menyemprot yang efektif. Sedangakan sekolah lapang merupakan pertemuan rutin yang dilakukan oleh penyuluh dengan petani yang bertujuan untuk meningkatkan pengetahuan petani mengenai suatu pembahasan tertentu. Seperti contoh sekolah lapang yang mengajarkan mengenai padi organik di Sidomukti. Sekolah lapang di Sidomukti, Salatiga dilakukan sebanyak 10 kali pertemuan, dan setiap pertemuan petani mendapat pesangon Rp.70.000. Hal itu itu bertujuan untuk meningkatkan minat petani untuk mengikuti kegiatan sekolah lapang tersebut.

\section{Proses Kegiatan Penyuluhan}

Petani yang memperoleh pelatihan penyuluhan hanyalah petani yang tergabung pada kelompok tani. Salah satu fungsi kelompok tani adalah melakukan pertemuan. Pertemuan di Sidomukti, Salatiga dilakukan rutin oleh penyuluh pertanian dengan kelompok tani. Pertemuan rutin akan dilaksanakan setiap 30-35 hari sekali. Di dalam sebuah pertemuan rutin antara kelompok tani dengan penyuluh, akan membahas semua keperluan kelompok. Petani juga saling bertukar pikiran antar anggota, diskusi bersama dan pemecahan masalah bersama. Berikut adalah pernyataannya penyuluh:

"Sebenernya sebulan sekali itu wajib ada pertemuan kelompok tani. Karena salah satu ee fungsi kelompok tani adalah kelas belajar, kelas usaha, sebagai sarana bertukar pikiran antar anggota. Disitu akan nanti ada ee diskusi dan pemecahan masalah, ee kegiatan kelompok tani itu apa, yang akan dicapai apa, evaluasinya seperti 
apa. Fungsi kelompok tani, salah satu ya, salah satu yang wajib adalah pertemuan".

Pertemuan rutin pasti dilakukan oleh penyuluh dengan petani. Hal itu bertujuan untuk mengetahui bagaimana progres petani, rancangan kerja, tujuan apa yang ingin dicapai dan juga evaluasi dari sebuah kegiatan. Penyuluh pertanian di Sidomukti memiliki sifat yang fleksibel. Dimana penyuluh bisa datang kapan saja saat mendapatkan panggilan dari petani.

Proses adopsi teknologi dan pelatihan yang diberikan penyuluh, semua bergantung kepada petani untuk menerapkan atau tidak. Tetapi sebagian besar pelatihan yang diberikan penyuluh akan diterapkan oleh petani. Pengalaman bertahun-tahun menjadi petani memang akan sulit jika datang sebuah inovasi baru yang belum jelas bagaimana hasilnya nanti. Biasanya petani akan bertanya atau berbagi informasi kepada petani lain yang sudah menerapkan teknologi baru dari penyuluh. Seperti penggunaan pupuk, jarak tanam, cara pengendalian hama dan benih baru apakah berhasil atau tidak. Petani yang melihat inovasi baru yang berhasil tersebut, akan menerapkan tehnik yang sama juga. Berikut adalah kutipan pernyataan dari petani padi:

"Ya terapke to mas. Soal-soal pupuk berimbang itu kan. Yaa itu, jarak-jarak, masalah pemupukan, masalah umur tanam itukan harus nganu kurang. Angger petani mau mengikuti opo enggak, kan gitu mas" (Tergantung petani mau mengikuti atau tidak, begitu mas).

Petani juga mengungkapkan, kegiatan atau pelatihan yang dilakukan oleh penyuluh cukup relevan dengan masalah yang dihadapi oleh petani. Petani mengungkapkan, disaat melakukan penyuluhan, petani juga bisa mengutarakan apa yang menjadi masalah mereka. Di suatu forum, petani dan penyuluh akan menyelesaikan masalah bersama yang tertera pada pernyataan petani padi di bawah ini:

"Masalahnya petani ee penyuluh datang kesini itu akan bahas apa yang ada di ini yaa mas yaa, keluhan petani. Jadi disitulah kita setiap ada pertemuanlah ada ada ini yaa ada penyuluhnya yaa kita utarakan nganu apa, masalah-masalah yang ada di ini. Kekurangane apa, kelebihane apa, kita bahas di pertemuan itu"

\section{Respon Petani}

Penyuluh di Sidomukti, Salatiga beranggapan bahwa petani padi di Sidomukti terlihat antusias jika diberikan kegiatan pelatihan penyuluhan. Terlepas dari kegiatan pelatihan, petani di Sidomukti juga akan sering diundang ke Dinas Pertanian Salatiga untuk menghadiri pertemuan yang membahas banyak hal. Memberikan informasi pasar, informasi teknologi, distribusi pupuk, harga benih dll. Dengan memberikan banyak informasi dari pemerintah mengenai banyak hal, petani akan tertarik melihat perkembangan 
pertanian. Selain memberikan informasi, petani juga pasti akan dimudahkan jika ikut kegiatan pertemuan atau penyuluhan. Petani yang datang akan di data dan biasanya akan diberikan bantuan seperti pupuk bersubsidi, penyebaran benih baru dll. Penyuluh di Sidomukti juga mengungkapkan, jika kehadiran petani bisa mencapai $80 \%$ dari yang yang diperkirakan, penyuluh akan menganggap petani di Sidomukti sangat antusias dalam pertemuan yang diadakan.

\section{Perubahan Hasil Panen}

Hasil panen yang maksimal adalah harapan semua petani. Untuk mendapatkan hasil panen yang maksimal, petani harus melakukan perlakuan tepat pada tanaman. Dari proses pemilihan benih, penanaman, perawatan dan pemberian pupuk harus dilakukan dengan tepat agar tanaman dapat menghasilkan panen yang maksimal. Penyuluh selalu mengupayakan agar petani menjadi lebih sejahtera dengan cara meningkatkan hasil panen tanaman padi mereka.

Penyuluh tani di Sidomukti Salatiga mengatakan, perubahan hasil panen pada petani setelah diberikan penyuluhan itu pasti ada. Tetapi tidak dengan terusmenerus hasil panen meingkat. Ada kala hasil panen tidak selalu meningkat karena dipengaruhi berbagai faktor. Produktivitas padi sangat berbeda ketika musim hujan dan musim panas. Ketika musim hujan, produksi padi tidak akan lebih dibanding dengan hasil panen musim panas. Hal itu dikarenakan ketika musim hujan terdapat banyak hama di ekosistem sawah dan juga padi yang kekurangan sinar matahari setiap harinya. Penyuluh juga sudah memberikan berbagai solusi untuk pencegahan dan pengendalian hama. Tetapi faktor seperti itu adalah faktor alam yang tidak bisa dihindari. Berbeda dengan musim panas, hasil panen tanaman padi akan lebih banyak dibanding dengan musim hujan. Tak hanya penyuluh, petani pun beranggapan demikian.

Setelah kegiatan penyuluhan, penyuluh di Sidomukti yang tergabung dalam Dinas Pertanian Salatiga akan melakukan evaluasi. Evaluasi ini sangat berguna untuk mengatahui berbagai faktor. Beberapa faktor dilakukannya evaluasi adalah untuk mengetahui perubahan hasil panen setelah diberikan penyuluhan, untuk mengetahui masalah apa yang belum terselesaikan dan juga untuk rencana kegiatan kedepan.

Terdapat 3 kategori evaluasi yang dilakukan oleh penyuluh di Dinas Pertanian Salatiga. Evaluasi pertama adalah evaluasi pra penyuluhan. Evaluasi ini dilakukan sebelum melakukan penyuluhan. Dapat 
dikatakan evaluasi persiapan sebelum dilakukannya penyuluhan. Evaluasi kedua adalah evaluasi penyuluhan. Evaluasi penyuluhan adalah penyebaran kuesioner kepada kelompok-kelompok tani. Kuesioner tersebut berisi bagaimana proses penyuluhan yang dilakukan, relevan atau tidak penyuluhan yang diberikan, kebutuhan apa lagi yang diperlukan petani untuk kegiatan penyuluhan berikutnya dll. Dan evaluasi ketiga adalah evaluasi setelah kegiatan khusus penyuluhan. Seperti contoh evaluasi khusus setelah pelatihan padi organik. Tetapi evaluasi yang pasti dilakukan oleh penyuluh, adalah evaluasi akhir tahun atau evaluasi penutupan tahun.

\section{KESIMPULAN DAN SARAN Kesimpulan}

1. Terdapat berbagai upaya yang dilakukan penyuluh dalam meningkatkan hasil panen petani padi di Sidomukti Salatiga. Pertemuan rutin dengan penyuluh, gerakan pengendalian, anjangsana, demplot dan sekolah lapang merupakan beberapa metode yang dilakukan oleh penyuluh.

2. Terdapat perubahan hasil panen dan pengetahuan petani akibat adanya penyuluhan pertanian. Penyuluh pertanian membantu mengajarkan petani bagaimana bertani yang lebih efektif dan memberikan berbagai kemudahan. Penyuluh memberikan berbagai informasi-informasi baru, informasi pasar, pemberian benih unggul, perawatan dan kemudahan pupuk. Sehingga petani lebih dimudahkan dan mendapatkan ilmu baru. Dan hasil akhir yang dicapai ialah perubahan hasil dan pengetahuan yang dapat meningkat.

\section{Saran}

Penyuluh perlu menarik generasi muda atau melakukan regenerasi untuk pertanian padi. Rata-rata petani padi memiliki umur yang sudah cukup tua. Umur yang sudah tua akan sulit melakukan pekerjaan dari segi fisik dan penerimaan ilmu baru. Oleh karena itu, penyuluh sepertinya perlu melakukan program untuk menarik generasi muda atau setidaknya melakukan regenerasi untuk pertanian padi yang lebih baik untuk kedepannya.

\section{DAFTAR PUSTAKA}

Amanah, S. (2007). Makna Penyuluhan dan Transformasi Perilaku Manusia. Jurnal Penyuluhan .

Herdiyansah, H. 2010. Metode Penelitian Kualitatif untuk Ilmu-ilmu Sosial. Jakarta: Salemba Humanika.

Moleong, J. L. 2000. Metodologi Penelitian Kualitatif. Bandung: PT. Remaja Rosdakarya. 
Neuman, W. L. 2003. Social Research Methods, Qualitative and Quantitative Approaches. Fifth Edition. Boston: Pearson Education

Sapar, dkk. (2012). Kinerja Penyuluh Pertanian dan Dampaknya pada kompetensi Petani Kakao di Empat Wilayah Sulawesi Selatan. Jurnal Penyuluhan, Vol. 8 , No. 1
Sugiyono. (2011). Metode Penelitian Kuantitatif, Kualitatif, dan R \& D. Bandung: Alfabeta.

Yanto, N. (2016). Implementasi Kebijakan Penyuluhan Pertanian pada Penyuluh Pertanian Lapangan (PPL) di Badan Pelaksanaan Penyuluh Pertanian, Perikanan dan Kehutanan (BP4K) Kabupaten Karawang. Thesis (S2), UNPAS. 